\title{
DISTANCE EDUCATION IN HISTORICAL ASPECT
}

\section{Tālmācība vēsturiskajā skatījumā}

\author{
Irena Katane \\ Latvia University of Agriculture, Latvia \\ E-mail: Irena.Katane@inbox.lv \\ Edgars Katans \\ Latvia University of Agriculture, Latvia \\ E-mail: Edgars.Katans@gmail.com \\ Gita Vavere \\ Latvia University of Agriculture, Latvia \\ E-mail: Gita.Vavere@talmacibasvsk.lv
}

\begin{abstract}
In this article the authors give theoretical substantiation to the ideas of distance education, as well as offer an insight into the development of distance education, where the experience of many countries is summarized. The aim of the article is to publish the results of the theoretical research on the history of distance Education. As a result of research, the authors drew several conclusions: 1) since the $18^{\text {th }}$ century, when the first attempt of distance education had been registered, till nowadays the humankind has amassed rich experience in this sphere;2) the correspondence education is the initial form of distance learning; 3) the development of distance education in the $20^{\text {th }}$ century was facilitated by the development of information and communication technologies and their introduction into education; 4) in connection with the development of distance education, a new direction - media pedagogy began its development in pedagogy.
\end{abstract}

Keywords: open educational environment, accessibility of education, distance education.

\section{Introduction}

The education of the $21^{\text {st }}$ century is characterized by the keywords humanization of education, openness and accessibility of educational environment, diversity of education, globalization of education, and sustainability of education. The humanization, accessibility, openness and diversity of educational environment are the guarantee of the sustainable development of education.

The ideas of humanization, democratization, including, the ideas of accessibility, could be found already in the works of great thinkers of Renaissance that became the source for the development of the conceptions of extramural education. Distance learning is one of the forms of extramural education.

The most rapid development of distance learning took place in the $20^{\text {th }}$ century.

Distance learning has become more topical during the last decade as an alternative to the traditional educational process. Asone of the forms of extramural education, distance learning, first of all, related to the broadening of opportunities offered in connection to home education under home environment and international education or crossborder education.

In the $20^{\text {th }}$ century distance learning was mostly spread in higher education, then, thanks to the development of the methodology of distance learning and the introduction of new technologies in education, distance learning became accessible 
also at the level of secondary and even basic education. Thus the significance of teachers' competencies becomes more important in the field of the methodology of distance learning.

Our experience proves that the audience of distance learning is rather wide: students of school age and grown-up students; the employed and the nonworking population; people who could not fit into the traditional educational system due to different reasons; people who resume their education again by choosing the second chance education to be obtained in a way of distance learning; people with special needs a.o.

In order the process of distance learning would be successful, so that it would truly serve the democratization and humanization of education, it is necessary to study the history of the development of distance learning, relating the ideas of distance learning to the ideas of the humanization and democratization of education. The aim of the article is to publish the results of theoretical research performed by the authors of the article on the history of distance education.

\section{Materials and Methods}

In order to perform research, aggregate, analize and evaluate information about the developmental history of distance learning, the authors of the article carried out research in different directions.

- The ideas of the humanization and democratization of education in the developmental history of pedagogical ideas, including the origin of the ideas of lifelong education.

- The conceptions of an open school, open education and open, humanistic target oriented educational environment.

- The origin and developmental history of distance learning as a form of extramural education.

Research methods: 1) the study, theoretical analysis and evaluation of scientific, methodological literature and different documents; 2) reflection of authors' personal experience in the field of distance learning.

\section{Results and Discussion}

The origin of distance learning ideas is connected with the ideas of humanization and democratization of education, first of all, with the ideas of accessibility of education for the whole nation, irrespective of people's social status, welfare level, sex and age, level of preliminary knowledge etc.

Such ideas were already expressed by J. A. Comensky, who developed and substantiated an educational conception, where the basic requirement was to teach "profoundly everything to everyone in all kinds of ways". It was a brave, even revolutionary idea in a social and political sense: 1) everyone meant the poor and the rich, the noble and the needy, the girls and the boys, as gentlemen and the servants, the old and the young; 2) everything meant the united concept and totality of views about the world, that expands during the lifespan of a person (as the annual rings of trees) on the basis of cycles; 3) profoundly meant braod and systemic knowledge; 4) in all kinds of ways meant that J. A. Comensky anticipated the diversity of the acquisition of , its alternative forms that could ensure the accessibility of education. Thus, the basis of 
J. A. Comensky's educational conception includes the idea of lifelong education that is grounded on the principles of humanization and democratization of education. J. A. Comensky was one of the first who had his own vision of lifelong education that indicated a new direction in the development of pedagogy, namely, the development of evolutionary pedagogy. J. A. Comensky pointed out several stages of lifelong education, substantiation of which is based on the idea of the periodization of age stages and the principle of nature correspondence (Васильева, 2002; Кларин, Джуринский, 1988; Хапаева, 2007).

Humanization and accessibility of lifelong education, as well as the diversity of educational environment became the basic idea for the development of lifelong education concept in the $20^{\text {th }}$ century.

In the second half of the $20^{\text {th }}$ century and at the beginning of the $21^{\text {st }}$ century one of the most important doctrines in the educational development are the concepts of open education, open educational environment, open school that in philosophy are defined as postmodern age (Collins, Greeno, Resnick, 1996; Kokse, 1999; Paul, 1996).

The concept of open education that emerged in the second half of the $20^{\text {th }}$ century and was developed at the beginning of the $21^{\text {st }}$ century is closely related to the conceptions of lifelong education and continuous education that are interconnected (Colletta, 1996, 22-27; Hasan, 196, 33-41; Sutton, 1996, 27-32).

The ideas of a school as an open environment gained a new quality and a new perspective at the end of the $20^{\text {th }}$ century, when the influence of the globalization processes on education increased. Alongside with the exchange of experience with the schools of western countries the ideas of an open school as an integral part of society emerged in Latvia.

For instance, it follows from the model of a school as an open system developed by I. Raituma (Raituma, 2009) that only a school formed by many variable elements (resources, educational services, programs) that are closely related to the elements of both external and internal environments could be considered as an open system.

In her turn, I. Katane (Katane, 2005; Katane, 2007), on the basis of ecological approach in research and education, has developed and scientifically substantiated a model of a rural school as open, humanistic target oriented educational environment where the school, in fact, is a multifunctional center of education and culture for the whole rural community.

Humanization and democratization of education are related not only to the ideas of lifelong education, but also to the respect towards the individual approach and to the principles of the individualization of education that actualize the respect towards the uniqueness of the personality of an individual who studies.

Individualization is a search of different ways in order to achieve the unified educational result. According to the technological aspect, the individualization system has precisely defined study aims that are determined by the observed action of the learner; the standardized materials, appropriate to the study aims, are used - they forecast the learners' actions and enable to work individually without the teacher's assistance. The essence of individualization, according to I. Maslo (Maslo, 1995), is seen in the effectiveness of studies and upbringing that enables to develop every 
child's talents and abilities. The scientist emphasizes that the individualization of studies envisages the united educational orientation, although these points are accessed using different ways. According to I. Maslo, the individualization of the pedagogical process at a school is one of the main pedagogical directions of the $21^{\text {st }}$ century:

- individualization shall facilitate the development of both all pupils and every individual child at the same time;

- the individualization of studies shall be related to the whole study process, not only to its particular stages;

- teachers shall think about the differentiation of the exposition of study content, type and pace of acquisition;

- individualization can be successful only, when the teacher has appropriate materials (variants of the exercises, materials for the group work, etc.) that could be used for this purpose.

Individualization of education is interpreted differently at the present stage of modern pedagogy science (Собина, 2006):

- every pupil learns individually, independently from others, according to a specific study program, outside the system of forms-lessons; it means that the study process shall be oriented towards the pupils' individual psychophysiological peculiarities, instead of the average readiness of the pupils, the average level of development or progress; the pupils' individual differences and each pupil's individual peculiarities shall be taken into account within the study process;

- the respect towards the individual approach within the framework of the sydtem of forms-lessons, when the study process in the classroom is organized by giving: a) the same exercises to the whole form, but their fulfillment and evaluation is individual; b) differential exercises for the groups or individuals; c) appropriate and developmental exercises according to every pupil's abilities and preliminary knowledge, where the work in one classroom and time is explicitly individualized.

The basic viewpoints concerning the humanization, including individualization, and democratization of education, first of all, ensuring of accessibility, enabled several educators to come up with the ideas of distance education.

The origin of distance education could be found in the year 1728, when teacher Caleb Philip offered an opportunity to acquire knowledge, study materials on a regular basis (once a week) by sending them via mail (Tālmācības vēsture, 2011).

In 1836 London University was established, where the exams could be taken externally. These opportunities were used not only by the students of this university, but also by the students of other universities (Никитин, 2011).

The conception of correspondence studies emerged in the $19^{\text {th }}$ century and became the historical source of the conception of distance education. This conception of correspondence education became popular and was implemented in several countries by means of mail services. Several colleges were established that offered to acquire several university study programs via mail. In the year 1840 the distance education was implemented on the all territory of England. The main merits go to Isaack Pitman: his students translated the fragments of the Bible and sent them via 
mail for correction. This method was combined with the full-time studies of Scriptures, and later special tasks were also prepared. The new form of studies became the basis and the origin of the establishment of Isaac Pitman's Correspondence College. The traditions of distance education from England spread also in Germany. In 1856 the Frenchman Charles Toussaint and the German Gustav Langenscheidt established a correspondence school in Berlin, where languages could be mastered (Pittman, 1991; Хапаева, 2007).

The founder of the system of distance education in the USA was Anna Eliot Ticknor who established and was the director of the school of "homeschooling" ("Boston-based Society to Encourage Studies at Home") from 1873 till 1897. The studies were based on the exchange of letters between students and teacher, as well as on the specially designed tests. In 1873 Anna Eliot Ticknor also developed an educational model for women under the title "Ticknor's Society"; the model was based on the idea of the program implemented in Great Britain "The Society for the Assistance for Learning at Home". At that time (1882) such distance education was developed also in Japan (Anna Eliot Ticknor, 2008).

Several authors had the idea of correspondence studies at the same time. One of them was W. R. Harper, who introduced the alternative type of education in the USA in 1890, where the studies were possible by means of written communication via mail services; thus education became more accessible to those who: 1) could not leave their places of residence to go to the city universities to study as full-time students, 2) did not belong to elite. In 1892 William Rainey Harper established the Department of Extramural Studies at Chicago University, USA. The correspondence education as a form of extramural studies gained support, and it was some kind of protest against the undemocratic and inelastic educational system in several European countries and the USA, especially regarding the rural inhabitants. In 1906 the correspondence studies via mail were introduced at the University of Wisconsin (Pittman, 1991; Никитин, 2011; Хапаева, 2007).

At the beginning of the $20^{\text {th }}$ century the elements of distance education regarding the use of mail services were introduced also in Russia: at Nahodka Naval School (1906), as well as at Moscow University named after A.M. Shanavsky (1908). The education via mail started to spread also in Australia and Canada. After 1917 a special model of extramural education was developed in Russia within which there was also the correspondence through mail envisaged. In 1960ies there were already 11 universities in the U.S.S.R. that had the departments of extramural education (studies) (Никитин, 2011).

Advocating "wireless university", famous educationalist and historian J. C. Stobart wrote to recently established BBC Company in 1926, substantiating the advantages of distance education at an Open University. In his turn, R. C. G. Williams argued for and implemented in practice the idea of "tele-university", namely, while working at the Institution of Electrical Engineers, he offered his prepared broadcast lectures combined with in advanced specially prepared and in advance sent through mail the broadcast lecture materials. R. C. G. Williams offered such lectures also at the traditional universities, introducing in education the multi-media concept (History of the Open University, 2011). 
In 1938 the first congress of International Council for Distance Education took place in Canada, where the issues of correspondence education (education via mail) were discussed (Open Learning and Distance Education .. , 1999).

As the development of the radio took place already during the World War I, but the television became a part of everyday life in 1950ies, it influenced also the development of educational environment. The conceptions of outdoor education emerged that were based on the accessibility and individualization of education, ensuring more opportunities for the development of homeschooling. Sound, video recordings, television, radio records became the important and widely accessible learning materials (Gunawardena, McIsaac, 2004). These materials laid the foundation for the media pedagogy.

In March 1963 the representatives of the UK Labour Party, who dealt with the issues of educational policy, under the chairmanship of Lord Taylor presented on the accessibility of higher education for all those interested in, even for the representatives of working class. They suggested carrying out an experiment using radio and television, establishing the University of the Air, within the framework of which the serious, sustainable conception of adult education would be developed and implemented according to plan. H. Wilson, the leader of the Labour Party was particularly inspired by the idea of distance education. He took an active part in the preparation and implementation of the project of the University of the Air (later called the Open University) by inviting several organizations to take part in it. Jennie Lee, the Minister for the Arts of Great Britain, held the same views and became the partner of $\mathrm{H}$. Wilson. Thanks to her persistence and fortitude, 'the wall' of the lack of understanding and even stagnation in thinking was destroyed and there were established contacts in the spheres of education and culture with Chicago (the USA) and Moscow (the U.S.S.R.). The official document about the establishment of the University of the Air was published in 1966 that, by the decision of the Cabinet of Ministers, was renamed Open University in 1967. The first student started to study at the Open University two years later (in 1971). H. Wilson, the prime minister, who won at the elections, monitored the project of the Open University himself. The Queen of Great Britain herself opened the Open University. All the necessary measures were taken in order the university would become accessible for the masses and at the same time would be also a prestigious educational intsitution. Mike Pentz, the first dean of the Faculty of Science, who was a very charismatic personality, contributed a lot in ensuring the accessibility of distance education. Thus, the Open University was established in Great Britain in 1969 that later became the largest educational institution, where 200,000 students from all over the world studied by means of distance education. The name of the university itself proves that the education there is accessibile and democratic, because the tuition fee in the university is low, as well the students do not have to attend regular academic lectures at the study-rooms of the university. The French National Centre for Distance Learning (CNED) was also established in 1969. The following facts show the volume of its functioning: 2,500 different study courses; 350,000 students; branches in 120 countries; about 5,000 members of teaching staff were involved in the development and delivery of study courses; the most modern technical equipment, including, satellite television, video 
and audio equipment, e-mail, Internet, as well as the traditional study aids. The Public Broadcasting Service (PBS TV) was established also in the USA. According to its essence, it was the consortium of 1,500 colleges and television companies. PBS TV offered several study programs that were broadcasted on four TV channels. The most significant were PBS Adult Learning Service programs in different fields, such as science, business and management (History of the Open University, 2011; Marwick, 1976; Краткая история дистанционного образования, 2003).

Later, alongside with the establishment of above mentioned institutions in Great Britain and France, similar establishments were opened also in other European countries, as well as Asia. The National Level Network of Radio and Television Educational Institutions was developed in China in 1979, where the study process was implemented by means of the satellites of the Earth. Particularly rapid development of distance education took place in the international educational environment thanks to the introduction of ICT in everyday life, including also education. The age of the Internet use in education began in the USA in 1980ies. For instance, in 1986 Charles Wedemeyer introduced the innovative media education at the University of Wisconsin, where all the opportunities of media were used, including also the latest information technologies, that was an important base for the development of distance education. The world-wide triumph of distance education started at the end of the $20^{\text {th }}$ century. Very noticeable is the National Distance Education University (UNED) in Spain with 58 study centers in 9 countries, and Baltic University (BU) with its main office situated in Sweden (Stockholm) unites the centers of distance education in 10 countries. The Pennsylvania State University is recognized nowadays as a very prestigious institution of distance education. Its experience was used by UNESCO specialists, when developing the conception of virtual university (Gunawardena, McIsaac, 2004; Никитин, 2011; Хапаева, 2007).

At the end of the $20^{\text {th }}$ century $25 \%$ of all distance education programs in the USA represented the commercial education. Such companies as General Motors, J. C. Penney, Ford, Walmart, FedEx, using the corporate educational networks, offer their specialists the courses for the improvement of professional skills. IBM uses the environment of satellite education (Краткая история дистанционного образования, 2003).

The Conception on the Establishment and Development of the Uniform Network of Distance Education was adopted in Russia in 1994 (Васильева, 2002; Никитин, 2011).

Distance education emerged in Latvia in 1990ies.

Distance education in Latvia is defined as a form for acquiring education, where the basis is independent studies, but the direct and continuous contact with the lecturer basically is not necessary, therefore it is replaced by video lectures and communication by means of ICT. In conformity with the Education Law of the Republic of Latvia (LR Izglitîbas likums, 1998), distance education is defined as an extramural method for acquiring education.

Nowadays several higher education institutions in Latvia offer distance education opportunities. Riga Technical University is a leading institution of higher education in the sphere of distance education. The aim of the Distance Education 
Study Centre of Riga Technical University is to develop the opportunities of distance education in Latvia for everybody at the easy accessible university level, using the modern world's experience of distance education and technologies (Kas ir RTU .. , 2011).

The Latvia University of Agriculture also improves its e-environment, considering the accessibility and internationalization of its educational environment.

In 2009 the first distance education secondary school - Riga Distance Education Secondary School - started its activities in Latvia. At present it is the only such school Latvia implementing the accredited programs of secondary and basic education.

According to the authors' point of view, distance education with its considerable advantages in comparison to the traditional method used for acquiring education has a wide range of perspectives concerning development in Latvia. This would enable to make the educational environment more flexible, accessible, where it would be possible to implement the individualization of education according to each person's age, preliminary knowledge, skills and competences, state of health, abilities, interests, needs and plans for future.

\section{Conclusions}

- The ideas of the humanization, including individualization, as well as democratization of education, particularly the ideas of accessibility, became the base for the search and implementation of distance education.

- Since the $18^{\text {th }}$ century, when there was registered the first attempt of distance education, until nowadays the mankind has amassed rich experience in this field. Distance education as an extramural method for acquiring education has spread all over the world, including also Latvia.

- Correspondence education is the initial form of distance education.

- The development of information and communication technologies and their introduction into education facilitated the development of distance education in the $20^{\text {th }}$ century.

- In connection with the development of distance education, a new direction media pedagogy — began its development in pedagogy.

\section{Bibliography}

1. Anna Eliot Ticknor 1823 - 1896. (2008). The Ticknor Society. [online] [20.10.2011]. Available at: http://www.ticknor.org/Anna.shtml

2. Colletta N.J. (1996). Formal, Nonformal, and Informal Education. In: Tuijnman A.C. (ed.). International Encyclopedia of Adult Education and Training. Second edition. France, Paris, Pergamo, pp. 22. - 27.

3. Collins, A., Greeno, J.G., Resnick, L.B. (1996). Environments for Learning. In: Tuijnman A.C. (ed.). International Encyclopedia of Adult Education and Training. Second edition. France, Paris, Pergamo, 960 pp.

4. Gunawardena Sh. N., McIsaac M. S. (2004) Distance Education. In Jonassen D. H. (ed.) Handbook of Research for Educational Communications and Technology, 2nd New Jersey: Lawrence Earlbaum Ass. Incpp, pp. 355 - 396. 
5. Hasan, A. (1996). Lifelong Learning. In: Tuijnman A.C. (ed.). International Encyclopedia of Adult Education and Training. Second edition. France, Paris, Pergamo, pp. 33- 41.

6. History of the Open University (2011). Open University. [online] [20.10.2011]. Available http://www.mcs.open.ac.uk/80256EE9006B7FB0/(httpAssets)/F4D49088F191D0BF80 256F870042AB9D/\$file/History+of+the+Open+University.pdf

7. Kas ir RTU tālmācības centrs? (2011). (What is RTU Distance Education?) Rīga, RTU. [online] [20.10.2011]. Available at: http://www.vu.lv/index.php?option=com_content\&view=article\&id=9\%3Akas-ir-rtutlmcbas-studiju-centrs\&lang=lv (In Latvian)

8. Katane, I. (2005). Lauku skolas kā izglìtības vides izvērtēšanas modelis (The Evaluation Model of the Rural School as Educational Environment). Promocijas darbs pedagogijas zinātnes skolas pedagog̣ijas apakšnozarē. Jelgava, Daugavpils, LLU TF IMI; DU, 195 lpp. (in Latvian)

9. Katane I. (2007). No ekologiskās paradigmas lìdz vides modelim izglìtības pētniecībā (From Ecological Paradigm till Environmental Model in the Research of Education). Monogrāfisko pētījumu sērija Izglītības ekologija. Jelgava, LLU, 239 lpp. (In Latvian)

10. Koķe T. (1999). Pieaugušo izglītības attīstība: raksturīgākās iezīmes (The Development of Adults Education: Characteristic Features). Rīga, Mācību apgāds NT, 102 lpp. (In Latvian)

11. Latvijas Republikas Izglitiibas likums (The Education Law of Republic of Latvia). (1998). Latvijas Vèstnesis, (17.11. 1998.), Nr.343. (In Latvian)

12. Marwick A. (1976). History of the Open University. Oxford Review of Education, Vol.2, No 2. [online] [20.10.2011]. Available at: http://www.jstor.org/pss/1050207

13. Maslo, I. (1995) Skolas pedagogiskāa procesa diferenciācija un individualizācija (The Differentiation and Individualization of Pedagogical Process of Schools). Rīga, RaKa, 172 lpp. (In Latvian)

14. Open Learning and Distance Education in Canada (1999). Canadian Association for Distance Education, Councils of Ministers of Education, Canada. [online] [23.09.2011]. Available at:

http://www.hrsdc.gc.ca/eng/hip/lld/olt/skills_development/oltresearch/cadeapec_e.pdf

15. Paul, R.H. (1996). Experiental and Open Learning. In: Tuijnman A.C. (ed.). International Encyclopedia of Adult Education and Training. Second edition. France, Paris, Pergamo, 960 pp.

16. Pittman, V. (1991). Rivalry for respectability: collegiate and proprietary correspondence programs. Second American symposium on research in distance education. University Park, PA: Pennsylvania State University.

17. Sutton, P.J. (1996). Lifelong and Continuing Education. In: Tuijnman A.C. (ed.). International Encyclopedia of Adult Education and Training. Second edition. France, Paris: Pergamo, pp. 22.-33.

18. Tālmācības vēsture (The History of Distance Education). (2011). Rīga, BVK. [online] [20.10.2011]. Available at: http://www.talmaciba.lv/lv/interesu-izglitiba-talmacibasvesture (In Latvian)

19. Васильева 3.И. (ред.). (2002). История образования и педагогической мысли за рубежом и в России (The History of Education and Pedagogical Though Abroad and in Russia). Москва, Академия, 416 с. (In Russian) 
20. Кларин В., Джуринский А. (сост.). (1988). Педагогическое наследие: Я.А. Коменский, Дж. Локк, Ж.Ж. Руссо, И.Г. Песталоцци (The Pedagogical Heritage). Москва, Педагогика, 412 с. (In Russian)

21. Краткая история дистанционного образования (The Brief History of Distance Education). (2003). Санкт-Петербург: Центр дистанционного образования «Элитариум». (In Russian)

22. Никитин А.Д. (2011). Информационны технологии в обучении (Informative Technologies in Teaching), [online] [23.09.2011]. Available at: http://asu.ugatu.ac.ru/library/46/ito_lekciya_9.pdf (In Russian)

23. Собина Т.А. (2006) Индивидуализация обучения и развитие способностей учащихся (Individualization of Teaching and Development of Pupils' Abilities ). Москва, Издательский дом «Первое сентября». [online] [02.11.2011]. Available at:http://festival.1september.ru/articles/310765/ (In Russian)

24. Хапаева С.С. (ред.). (2007). Дистанционное образование: опыт и перспективы (Distance Education: Experience and Perspectives). Вып. 4. Москва, Диона, 84 с. (In Russian)

\begin{tabular}{|cl|}
\hline Irena Katane & Latvia University of Agriculture, \\
& Institute of Education and Home Economics \\
& J. Čakstes bulv. 5, Jelgava, LV 3001, Latvia \\
& E-mail: Irena.Katane@inbox.lv \\
& Phone: +371 29110582 \\
\hline Edgars Katans & Latvia University of Agriculture, \\
& Institute of Education and Home Economics \\
& J. Čakstes bulv. 5, Jelgava, LV 3001, Latvia \\
& E-mail: Edgars.Katans@gmail.com \\
& Phone: +371 26229726 \\
\hline Gita Vavere & Latvia University of Agriculture, \\
& Institute of Education and Home Economics \\
& J. Čakstes bulv. 5, Jelgava, LV 3001, Latvia \\
& E-mail: Gita.Vavere@talmacibasvsk.lv \\
& Phone: +371 26468184 \\
\hline
\end{tabular}

